\title{
Liquid Crystal Modes for Display Applications
}

\author{
Jung-Wook Kim and Tae-Hoon Yoon $^{\dagger}$ \\ Department of Electronics Engineering, Pusan National University, Busan 609-735, Korea
}

(Received July 15, 2013; Revised manuscript August 8, 2013; Accepted August 8 2013)

\begin{abstract}
An information display device is a key component in the information society. A liquid crystal display is the most widely used among information display devices. However, its performance still needs to be improved in order to survive in competition with other information display devices. In this paper, we explain the structure and the operation principle of a liquid crystal display device and introduce our recent research activities on liquid crystal mode technology.
\end{abstract}

Keywords: Liquid crystal display, Liquid crystal mode

OCIS codes: (230.0250) Optoelectronics; (230.3720) Liquid-crystal devices

\section{디스플레이 응용을 위한 액정 모드 김정욱 · 윤태훈 ${ }^{\dagger}$ \\ 부산대학교 전자공학과 \\ 우 609-735 부산광역시 금정구 부산대학로 63 번길 2}

(2013년 7월 15일 받음, 2013년 8월 8일 수정본 받음, 2013년 8월 8일 게재 확정)

정보디스플레이 기술은 디지털 정보화 사회를 혁신적으로 변화시킨 원동력이다. 액정 디스플레이는 가장 대표적인 평판 디스 플레이로서 저소비전력, 경량, 박형 등의 장점을 앞세워 소형에서부터 대형에 이르기까지 다양한 응용분야에 널리 사용되고 있 다. 하지만, 더욱 고성능의 디스플레이를 구현하기 위해 끊임없이 연구가 지속되고 있다. 본 논문에서는 액정 디스플레이의 구조 및 구동원리에 대해 설명하고, 액정 모드 기술에 대해 본 연구실에서의 연구를 중심으로 소개하고자 한다.

Keywords: 액정 디스플레이, 액정모드

OCIS codes: (230.0250) Optoelectronics; (230.3720) Liquid-crystal devices

\section{I. 서 론}

디스플레이는 디지털 정보화 사회를 혁신적으로 변화시키 는 원동력으로서 과거 CRT(cathode ray tube)로부터 오늘날 의 평판 디스플레이(FPD: flat panel display)까지 진화를 거 듭하며 발전하고 있다. 평판 디스플레이는 비발광형 소자를 이용한 액정 디스플레이(LCD: liquid crystal display)와 발광 형 소자를 이용한 플라즈마 디스플레이(PDP: plasma display panel), 유기발광소자(OLED: organic light emitting diode) 등 이 있다. 이 중에서도 액정 디스플레이는 고명암비, 광시야 각, 저소비전력, 경량, 박형 등의 장점으로 smart phone, monitor, tablet $\mathrm{PC}$ 와 같은 소형 기기에서부터 TV와 같은 대 형 가전기기에 이르기까지 다양한 응용분야에 널리 사용되 고 있다. 최근 모바일 기기의 Full $\mathrm{HD}$ (high definition) 및 TV
의 UHD(ultrahigh definition) 구현에 있어 액정 디스플레이 는 가장 적합한 디스플레이로 평가 받고 있다. 다양한 평판 디스플레이 기술이 많은 발전을 이루고 있는 가운데서도 액 정 디스플레이는 소자 자체의 우수한 특성뿐만 아니라 신뢰 성, 안정성 및 생산 기술에서의 장점을 앞세워 평판 디스플 레이 시장의 압도적인 시장 점유율을 유지하고 있다.

최근 액정 디스플레이 모드의 기술 동향을 살펴보면 고속 응답 액정모드에 대한 연구가 활발히 진행되고 있음을 볼 수 있다. $3 \mathrm{D}$ 디스플레이의 경우 충분히 빠르지 못한 응답시간 으로 인하여 crosstalk, 낮은 휘도, flicker 현상과 같은 문제점 이 발생하고 있다. 이러한 문제를 해결하기 위한 근본적인 해결책은 고속응답 액정모드의 구현이다. 한편, 액정디스플 레이의 소비전력을 개선하기 위한 대표적인 기술인 field sequential 기술은 전력 소모를 $1 / 3$ 로 획기적으로 감소할 수

\footnotetext{
${ }^{\dagger}$ E-mail: thyoon@pusan.ac.kr

Color versions of one or more of the figures in this paper are available online.
} 
있을 뿐만 아니라, 해상도가 3 배 높아지는 장점까지 있다. 이 기술의 상용화를 위해서도 마찬가지로 고속응답 액정모드의 구현이 필수적으로 요구된다. 본 논문에서는 액정 디스플레 이의 구조 및 기본원리에 대해 설명하고, 액정 모드에 대한 기술을 본 연구실에서의 연구를 중심으로 소개하고자 한다.

\section{II. 액정 디스플레이의 동작원리 및 구조}

투과형 액정 디스플레이의 기본 구조를 그림 1에 나타내었다. 후면에서부터 backlight unit(BLU), 편광판, thin-film transistor (TFT) array 기판, color filter 기판, 그리고 편광판 순서로 구 성되어 있다. ${ }^{[1,2]}$ 하부 유리 기판에는 TFT array와 투명 전극 으로 형성된 화소 전극이 있고, 상부 유리 기판에는 color filter와 black matrix(BM) 및 공통 전극이 형성되어 있다. 액 정은 이 두 기판 사이에 수 $\mu \mathrm{m}$ 의 두께로 채워져 있다. 구동 원리는 광원의 빛이 편광판을 지나면서 편광된 빛이 액정층 을 지나면서 편광의 상태가 바뀌어 두 번째 편광판을 지나거 나 막히게 되는 원리이다. 편광된 빛이 액정층을 지날 때 액 정의 광학적 이방성에 의해 나타나는 위상지연(phase retardation) 효과를 이용해 편광의 상태를 제어하게 된다. 전압을 인가하 여 액정의 배열 상태에 따라 위상지연 값이 변하게 되는데, 빛의 투과율은 다음과 같은 수식으로 표현할 수 있다. ${ }^{[3]}$

$$
\mathrm{T}=\frac{1}{2} \sin ^{2}(2 \varphi) \sin ^{2}\left(\frac{\pi \Delta \mathrm{n}_{\text {eff }} \mathrm{d}}{\lambda}\right)
$$

이때, $\varphi$ 는 액정 director의 방향과 편광판의 광축 사이의 방 위각을 나타내며 $\Delta n_{e f f}$ 는 액정의 유효 굴절률 차이, $d$ 는 액정 층의 두께, $\lambda$ 는 빛의 파장을 나타낸다. 최대 투과율을 구현 하기 위해서는 액정 director의 방향과 편광판의 광축 사이가 $45^{\circ}$ 가 되고 $\left(\varphi=45^{\circ}\right)$, 액정층에 의한 유효 굴절률 차이가 $\lambda / 2$ 가 되도록 설계 $\left(\Delta n_{\text {effd }} d=\lambda / 2\right)$ 해야 한다.

액정 디스플레이는 사용 환경 및 구조에 따라 그림 2 와 같 이 투과형, ${ }^{[1,2]}$ 반사형 ${ }^{[4,5]}$ 반투과형 ${ }^{[4,6-9]}$ 액정 디스플레이로 나눌 수 있다. ${ }^{[10]}$ 투과형 액정 디스플레이는 backlight를 이용

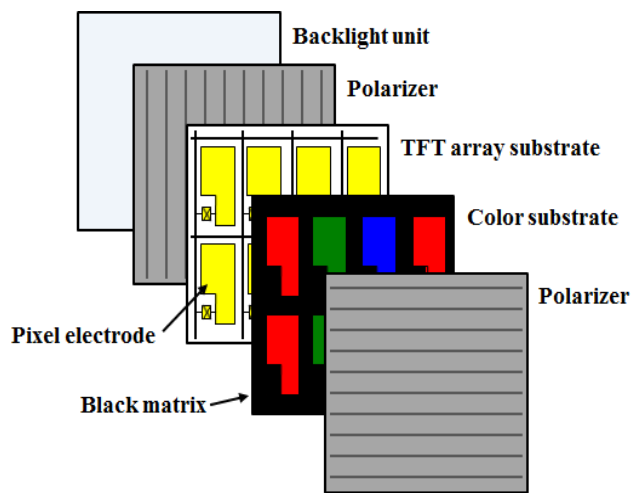

FIG. 1. Pixel structure of a transmissive liquid crystal display.
하며, 외부 광원이 약할 경우 혹은 실내에서 사용이 적합하 여 현재 대부분의 액정디스플레이에 적용되는 방식이다. 그 러나 야외에서 외부 광원이 강할 경우 시인성이 저하되는 문 제가 있다. 반면, 반사형 액정 디스플레이의 경우 햇빛 등의 외부 광원과 반사판을 이용하는 방식이지만, 실내와 같이 외 부 광원이 약한 환경에서는 화질의 저하가 발생하게 된다.

반투과형 디스플레이는 이 두 액정 디스플레이의 장점을 모아 놓은 것이다. 한 화소를 투과부와 반사부로 나누어 실 내외 구분 없이 우수한 시인성을 확보할 수 있는 구조이다. 하지만, 투과형이나 반사형보다 광효율이 낮으며, 제작 공정 이 복잡한 단점이 있다. 최근에는 두 패널을 이용해 화소 면 적 전체를 이용해 반사모드 혹은 투과모드로 사용할 수 있는 전반사/전투과 액정 디스플레이가 제안되기도 하였다. ${ }^{[1]}$

액정 디스플레이는 액정의 배향 상태와 전기장의 방향을 결정하는 전극 구조에 따라 다양한 액정 모드를 구현할 수 있다. 액정 기술 개발 초기에는 액정 분자의 꼬인 상태를 이 용하는 twist nematic(TN) 액정 모드가 주로 사용되었다. ${ }^{[12]}$ $\mathrm{TN}$ 모드는 공정이 간단하고 광효율이 우수하다는 장점이 있 지만, 실제 패널에 적용 시 storage capacitor로 인한 개구율 감소와 함께 시야각 특성에 문제가 있다.

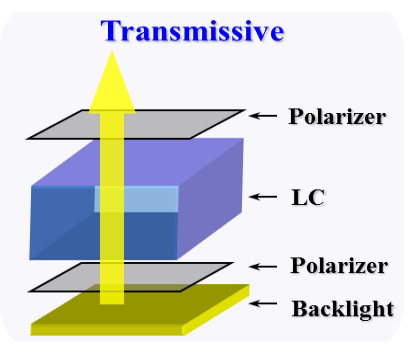

(a)

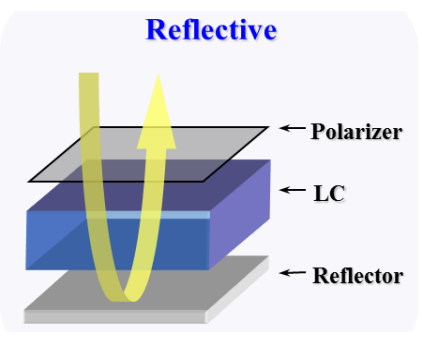

(b)

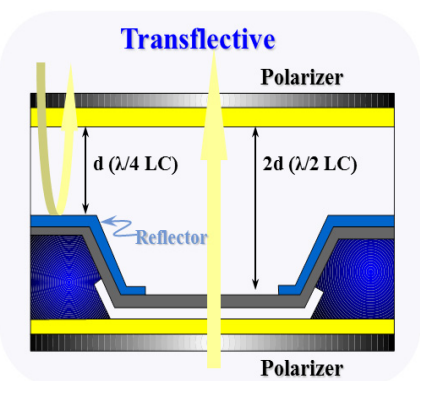

(c)

FIG. 2. Various types of liquid crystal displays (a) transmissive, (b) reflective, and (c) transflective. 
현재는 수직하게 배향된 액정을 이용한 수직배향(VA: vertical alignment) 모드 ${ }^{[13-15]}$ 와 수평하게 배향된 액정을 이용 한 수평스위칭(IPS: in-plane switching) 모드 ${ }^{[16,}{ }^{17]}$ 가 대부분 의 액정 디스플레이에 응용되고 있다. VA 모드는 우수한 dark 특성으로 높은 명암 대비비를 나타내는 반면, IPS 모드 는 우수한 시야각 특성을 나타내는 장점이 있다. 또 다른 액 정모드로는 electrically controlled birefringence $(\mathrm{ECB})$ 모드 $^{[18]}$ 와 optically compensated bend(OCB) 모드 ${ }^{[19]}$ 가 있다. 이 액 정 모드들은 고속응답 특성을 구현할 수 있지만, dark 특성 이 좋지 못해 명암 대비비가 낮다는 단점이 있다. 그 이외에 액정의 blue phase, ${ }^{\left[20,{ }^{21]}\right.}$ ferroelectric ${ }^{[22]}$ 액정을 이용한 모드 들도 개발되었지만, 복잡한 제조 공정 및 구동 방법으로 인 해 아직까지는 상용화 되지 못하고 있다. 전력소모를 최소화 하여 e-book 등에의 응용에 적합한 memory mode, ${ }^{[23]}$ dynamic mode와 memory mode를 스위칭하여 동영상을 디스플레이할 수 있으면서도 전력소모를 최소화할 수 있는 dual mode ${ }^{[24,25]}$ 에 대한 연구도 활발히 진행되고 있다. 본 논문에서는 가장 널리 사용되고 있는 VA 모드 및 IPS 모드에 대한 기술을 중 심으로 살펴보고자 한다.

\section{III. 수직배향 모드}

수직배향(VA) 모드는 그림 3에서와 같이 초기에 액정들이 수직으로 배열되어 있다. 음의 액정을 이용하여 상판과 하판 전극 사이에 전압을 인가함에 따라 액정의 극각이 달라지면 서 수식 (1)의 $\Delta n_{\text {eff }}$ 값이 변하면서 계조를 구현하게 된다. 최대 투과율을 구현하기 위해서는 전압이 인가되었을 때 액 정 director의 방향과 편광판의 광축이 $45^{\circ}$ 가 되도록 설계 $(\varphi$ $=45^{\circ}$ )하는 것이 중요하다. 동시에, 높은 전압을 인가하여도 상. 하 기판 표면의 액정 분자는 표면의 anchoring energy에 의해 스위칭 되지 못하기 때문에 설계 시 액정층에 의한 유 효 굴절률 차이는 $\lambda / 2$ 보다 조금 더 크게 설계해야 한다.

$\mathrm{VA}$ 모드는 매우 우수한 어두운 상태로 인해 높은 명암 대 비비를 나타내기 때문에 TV 등의 응용분야에 유리한 액정모 드이다. 하지만 액정 director의 극각이 변하게 될 때 유효 굴 절률의 크기는 시야각 방향에 따라 큰 차이를 보이게 된다. 이를 보완하기 위해 상판과 하판에 패턴전극 또는 protrusion

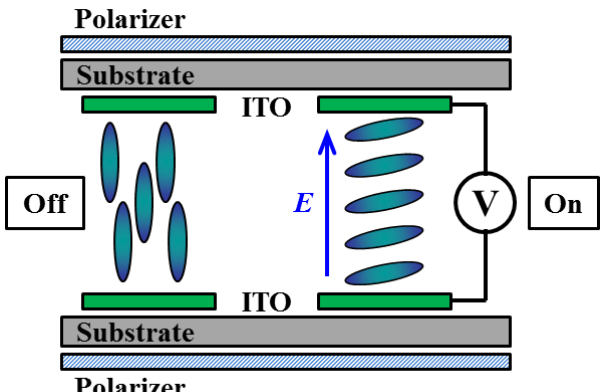

FIG. 3. Operation principle of the VA mode.
을 형성하여 각 domain 영역에서 액정의 스위칭 방향을 다 르게 하는 다양한 multi-domain 구조가 제안되었다. 최근에 는 그림 4(a)와 같은 micro-pattern 전극구조의 VA 모드가 제 안되었다. ${ }^{[2]}$ 하판의 4-domain으로 형성된 패턴 전극과 상판 의 공통 전극을 이용해 시야각 방향에 따른 유효 굴절률 차 이를 최소화할 수 있는 구조이다. 여기에 보상 필름을 적용 할 경우 매우 넓은 시야각 특성을 구현할 수 있다. 하지만, 이러한 multi-domain 구조는 그림 4(b)에서 보는 바와 같이 disclination line으로 인해 광효율이 낮아진다는 문제가 있다. 이는 밝은 상태 구현 시, 일부 액정이 편광판의 광축과 일치 하는 방향으로 스위칭 하게 되어 disclination line이 발생하 기 때문이다.

이러한 광효율 감소 문제를 개선하기 위해 다양한 방법들 이 제안되었다. ${ }^{[27]}$ 그림 $5(\mathrm{a})$ 와 같이 상판 전극에 slit을 형성 하고 하판 패턴 전극의 형태를 변형하게 되면, 편광판의 광 축과 일치하는 방향으로 스위칭되는 액정이 최소화 되면서 투과율이 최대 $20 \%$ 까지 개선될 수 있다. 이러한 전극 구조 는 고해상도 구현을 위해 픽셀 크기가 줄어들수록 더욱 큰 투과율 개선 효과를 보이기 때문에 향후 상용화 구현이 기대 되는 기술이다.

VA 모드가 multi-domain 구조를 이용해 시야각 방향에 따 른 유효 굴절률 차이를 최소화 하였지만, 여전히 측면에서

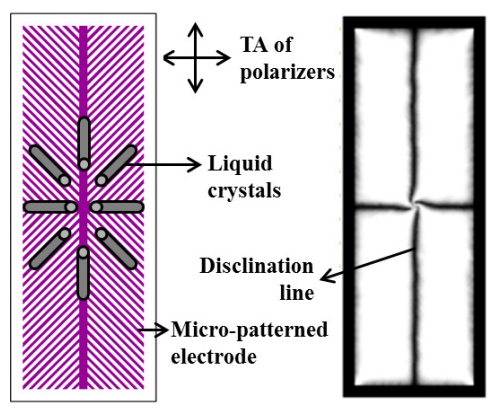

(a)

(b)

FIG. 4. Configuration of the VA mode with the micro-patterned electrode. (a) pixel electrode structure of the bottom substrate, and (b) top view image in the bright state.

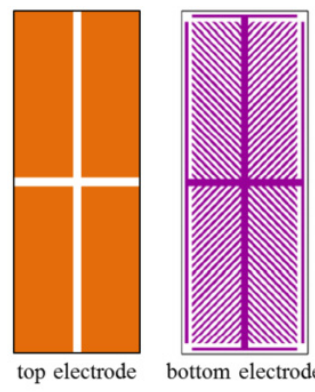

(a)

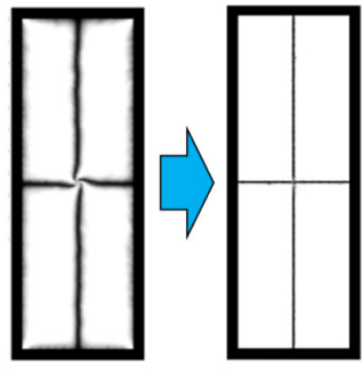

(b)
FIG. 5. (a) micro-patterned VA mode with the slit pattern on the top electrode, (b) improved transmittance. ${ }^{[27]}$ 
계조 곡선이 왜곡되는 문제점을 가지고 있다. 이러한 문제를 개선하기 위해서는 보상 필름을 이용해 어두운 상태 및 저계 조 구간에서의 계조 곡선 왜곡을 감소시킬 수 있다. 하지만 전 계조 구간의 계조 곡선을 개선하기 위해서는 super PVA(S-PVA) 기술이 적용되고 있다. ${ }^{[13]}$

S-PVA 기술은 한 픽셀을 두 개의 sub-pixel로 분할하여 각 sub-pixel에서 액정 director가 다른 극각을 가지도록 하는 기 술이다. 그림 6에 도식된 바와 같이 기존에 4-domain으로 이 루어져 있는 PVA 모드에 transistor 혹은 capacitor를 추가하 여 각 sub-pixel에 다른 전압을 인가하여 모두 8-domain 구조 를 형성할 경우 계조 곡선을 개선할 수 있다.

최근에는 한 픽셀을 세 개의 sub-pixel로 분할하여 계조 곡 선 왜곡을 최소화 하는 기술들도 제안되었다.[28] 이러한 S-PVA 기술은 PVA 모드와 비교해 계조 곡선을 훨씬 개선 할 수 있지만 transistor와 capacitor를 위한 공정비용 상승뿐 만 아니라, 개구율 감소 문제가 발생하게 된다.

이러한 복잡한 공정을 거치지 않고 sub-pixel을 구현하기 위한 기술들도 제안되었다. ${ }^{[29,}{ }^{30]}$ 배향막에 광개시제(photo initiator)를 도핑하고 액정에 reactive mesogen(RM)을 도핑한 뒤, photomask를 이용해 pixel의 일부 영역에만 UV를 조사 하여 폴리머 층을 형성하는 기술이다. 폴리머 층이 형성된 영역과 형성되지 않은 영역에서 액정층에 인가되는 유효 전 압의 차이로 인해 두 sub-pixel이 구현되는 기술이다.(그림 7) 또한 배향막에 $\mathrm{RM}$ 을 도핑하는 기술 및 배향막 표면의 anchoring energy 차이를 변화하는 기술과 같이 계조 곡선

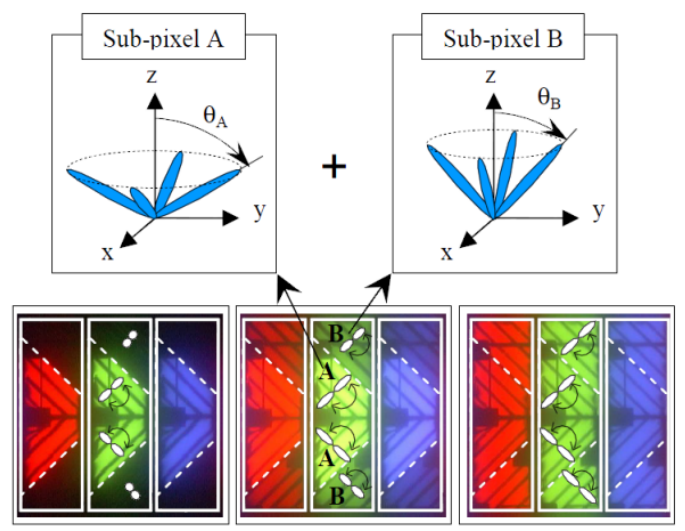

FIG. 6. 8-domain S-PVA mode. ${ }^{[13]}$

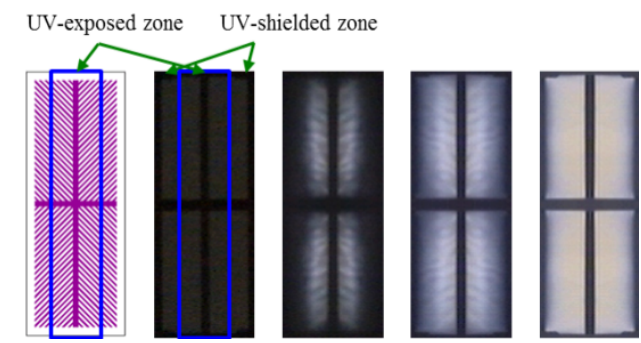

FIG. 7. 8-domain S-PVA mode using spatial adsorption of the photo-polymerized monomers. ${ }^{[2]}$
왜곡을 개선하기 위한 다양한 기술들이 제안되었다.

패턴 전극을 이용한 $\mathrm{VA}$ 모드들은 상판 전극과 하판 전극 사이에 전기장이 수직하게 인가되는 영역에서 액정들의 스 위칭 방향이 정해지지 않게 되어 순간적으로 disclination line 을 형성하게 된다. 이후 전기장이 경사진 영역으로부터 액정 들의 스위칭 방향이 전이되어 전기장이 수직한 영역에서 액 정의 스위칭 방향이 결정된다. 이로 인해 액정의 응답시간이 느려지게 되는 문제가 있다. 이러한 문제를 해결하기 위해 초기에 액정에 tilt를 형성하여 방향성을 정해주는 방안이 제 안되었다.

대표적인 방법이 polymer stabilized VA(PS-VA) 모드이다. $\left(\right.$ 그림 8) ${ }^{[31]}$ 액정에 $\mathrm{RM}$ 을 도핑하여 패널에 주입한 후 전압을 인가하여 모든 액정들이 스위칭 되었을 때 자외선을 조사하 여 배향막 표면에 유도된 $\mathrm{RM}$ 을 경화한다. 이때 표면의 액정 들은 경화된 $\mathrm{RM}$ 에 의해 초기 상태가 tilt가 형성된 상태가 되어, 전압 인가 시의 응답시간을 개선할 수 있다. PS-VA 모 드가 액정에 $\mathrm{RM}$ 을 도핑하는 것과는 달리, 배향막에 $\mathrm{RM}$ 을 도핑하여 액정에 tilt를 형성하는 기술도 제안되었다.(그림 9) ${ }^{[32]}$ 또 다른 방법으로는, $\mathrm{RM}$ 을 이용해 픽셀 내부에 polymer 기 둥을 형성하여 multi-dimension anchoring energy를 이용한 응답시간을 개선하는 방법도 제안되었다. ${ }^{[14]}$

한편, 음의 액정이 아닌 양의 액정을 이용한 고속응답 액 정모드들도 제안되었다. 수직 배향된 액정을 수평전계를 이 용하여 스위칭 하는 vertically-aligned in-plane switching (VA-IPS) 모드는 높은 구동전압으로 인해 아직까지는 상용 화에까지는 이르지 못하였지만, 수직배향된 양의 액정에 수

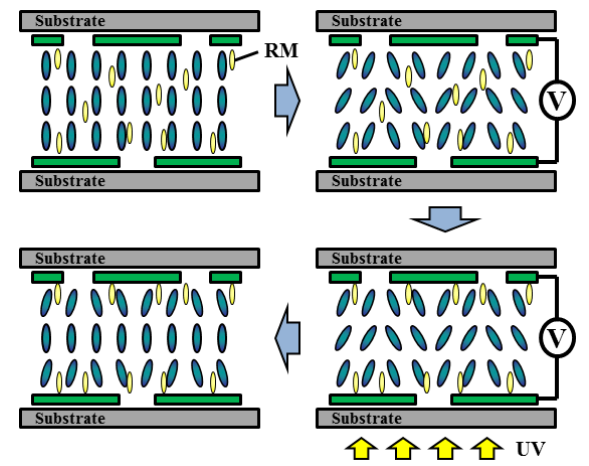

FIG. 8. Fabrication process of the PS-VA mode.

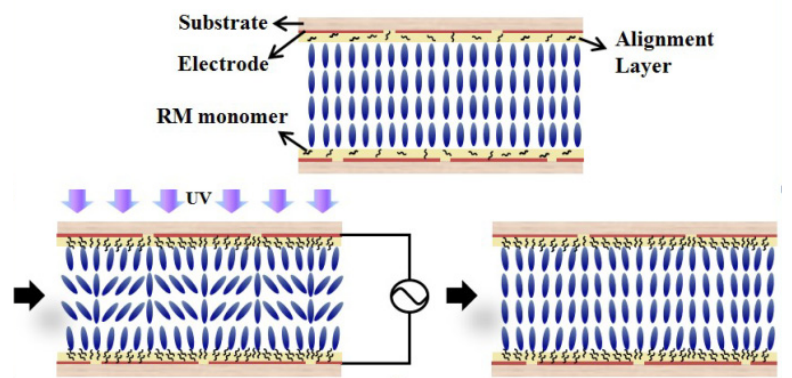

FIG. 9. Fabrication process of the surface-controlled VA mode. ${ }^{[32]}$ 
평 전계를 인가하여 빠른 응답시간을 나타낼 수 있다.(그림 10$)^{[33]}$ 최근에는, 복잡한 제조 공정이 문제점으로 남아있긴 하지만, 양의 액정을 이용해 sub-millisecond 응답시간을 구현하는 방 안도 제안되었다. ${ }^{[34]}$

\section{IV. 수평스위칭 모드}

수평스위칭(IPS) 모드는 그림 11(a)에서와 같이 초기 액정 이 편광판의 광축과 나란한 방향으로 기판에 나란하게 배향 되어 어두운 상태를 나타낸다. IPS 모드는 양의 액정을 이용 하여 하판의 패턴 전극에 전압을 인가함에 따라 액정 director의 방위각이 달라지면서 수식 (1)의 $\varphi$ 값이 변하여 계 조를 구하게 된다. 기판에 수평하게 배향된 액정 분자들이 균일한 방향으로 스위칭 되게 하기 위해서는 액정의 director

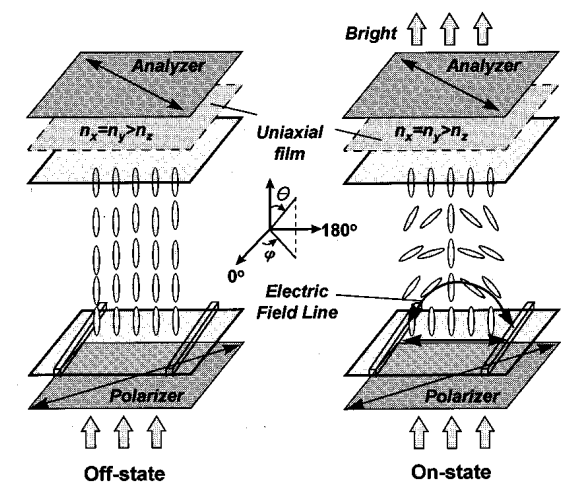

FIG. 10. Device structure and operation principle for in-plane switching of vertically-aligned positive LCs. ${ }^{[33]}$

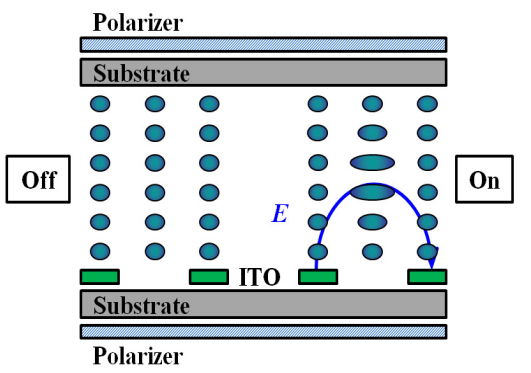

(a)

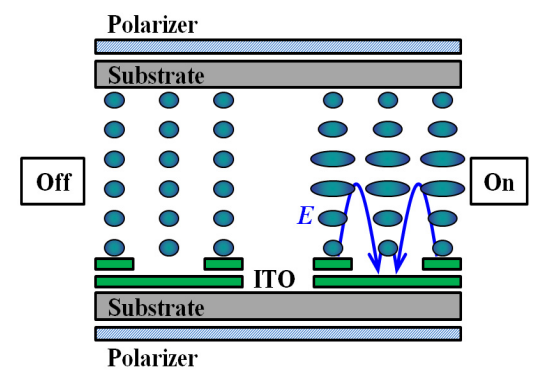

(b)

FIG. 11. Operation principle of the IPS and FFS modes.
방향과 패턴 전극의 방향이 나란하지 않도록 설계해야 한다. 액정 director 방향과 패턴 전극 사이의 각에 따라 액정 디스 플레이의 투과율 및 구동 전압은 크게 변화하게 된다. 현재 대부분의 수평배향 액정모드에서는 약 $7^{\circ}$ 가량의 차이가 나 도록 설계하고 있다. 또한, VA 모드와 마찬가지로 IPS 모드 역시 설계 시 액정층에 의한 유효 굴절률 차이는 $\lambda / 2$ 보다 조 금 더 크게 설계해야 한다.

액정 director의 방위각이 변하게 될 때는 시야각 방향에 따른 유효 굴절률 이방성의 크기 변화는 미미하기 때문에 보 상필름을 사용하지 않더라도 좌우 대칭적인 좋은 시야각 특 성을 나타낸다. 또한, touch 시에 화면의 왜곡 현상이 작아 대부분의 모바일 기기에는 수평배향 액정모드가 적용되고 있다. 하지만, 수직배향 액정모드에 비해 명암 대비비가 다 소 낮을 뿐 아니라, 일부 대각 방향에서 color shift와 gray inversion이 나타나는 문제점이 있다. ${ }^{[35]}$ 최근에는 광배향을 이용해 액정들을 배향함으로써 선경사각을 0 에 가깝게 만들 어 대각 방향에서의 왜곡 현상을 개선하기 위한 연구들이 지 속적으로 진행되고 있다.

기존의 IPS 모드에서는 전극 윗부분에서의 투과율 감소로 인한 낮은 광효율이 단점으로 지적되었다. 이를 보완하기 위 해 FFS 모드 (그림 11(b))가 제안되었다. FFS 모드는 기본적 으로 IPS 모드와 유사하지만, 전극 구조에 있어 패턴 전극 아래 통전극을 이용한다는 차이점이 있다. 패턴 전극과 이 통전극을 이용해 전압을 인가할 경우 전극 윗부분의 액정들 까지 회전하게 되어 더욱 높은 광효율을 구현할 수 있다. 최 근에는 IPS의 패턴 전극을 bipolar 전압으로 구동하는 방법 을 이용해 전극 윗부분의 투과율 감소를 개선하는 방법도 제 안되었다.(그림 12) [36] $^{[36}$

IPS와 FFS 모드는 액정의 수평 스위칭을 이용해 계조를 구현하기 때문에 액정의 twist deformation을 나타내는 탄성 계수 $K_{22}$ 의 영향을 받게 된다. 이는 액정의 splay 및 bend deformation을 나타내는 탄성 계수 $K_{11}, K_{33}$ 보다 낮은 수치 이기 때문에 응답 시간이 느리다는 단점이 있다.

이러한 수평배향 액정모드의 응답 시간을 개선하기 위한

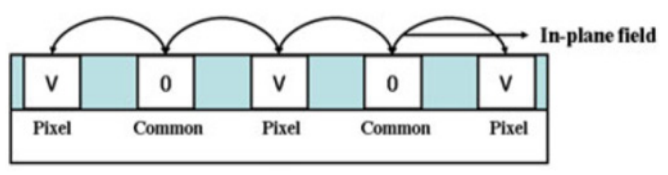

(a)

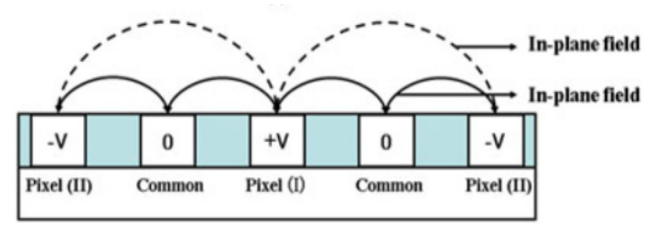

(b)

FIG. 12. Electrode structure of (a) unipolar IPS and (b) bipolar IPS for high transmittance. ${ }^{[36]}$ 


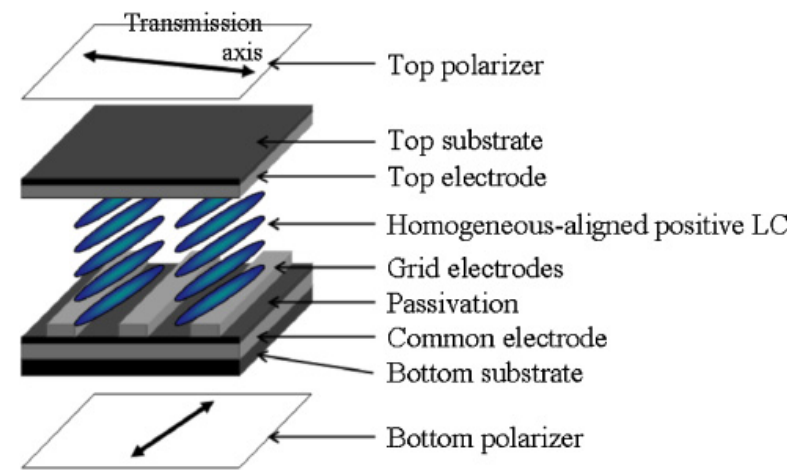

FIG. 13. Homogeneously aligned LC cell with the three-terminal electrode structure. ${ }^{[37]}$

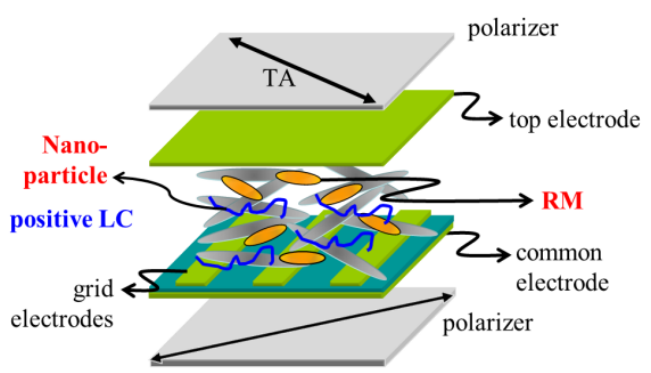

FIG. 14. Non-alignment LC cell with the three-terminal electrode structure. $^{[38]}$

방법으로 3 전극 구조를 이용한 방법이 제안되었다. ${ }^{[37]}$ 그림 13 에 나타난 바와 같이 하판의 전극은 패턴 전극과 통전극으로 이 루어져 있으며, 상판의 전극은 통전극으로 이루어져 있다. 계조 구현 시 하판의 전극을 이용해 전압을 인가하는 것은 기존의 수평 스위칭 액정 모드와 동일하지만, 매 frame 사이 에 상판의 전극을 이용해 수직 pulse를 인가하는 구조이다. 이 구동 방법을 적용하게 되면 액정은 수평 상태에서 스위칭 하지 않고, 수직으로 상태로 스위칭된 이후 수평으로 스위칭 하여 계조를 구현하고, 다시 수직 상태로 정렬되어 어두운 상태를 구현하게 되어 기존의 수평 스위칭 액정모드의 계조 구간 응답 시간을 $75 \%$ 까지 개선할 수 있다.

또 다른 고속응답 액정모드로는 기존의 배향막을 이용한 액정모드의 응답시간 한계점을 극복하기 위해 배향막을 사 용하지 않은 무배향 3 전극 액정모드가 제안되었다. (그림 14$)^{[38]}$ 배향막에 의한 액정의 배열이 아닌, 전기장에 의해 액정들이 배열하는 구조이다. 배향막을 제거함으로써 배향막 표면의 anchoring energy를 약하게 만들어주고, 어두운 상태 및 밝은 상태를 모두 수직 및 수평 전계를 이용해 구동함으로써 2 $\mathrm{ms}$ 이내의 아주 빠른 응답시간을 구현 할 수 있다. 동시에 $\mathrm{RM}$ 과 rod-like 형태의 나노입자를 도핑하게 되면 기존의 FFS 모드와 동등한 수준의 투과율을 구현하면서도 아주 빠 른 응답시간을 구현 할 수 있는 액정모드이다.

최근에는 저온에서의 응답시간 또한 차량용 디스플레이 응 용에 있어 주요 이슈로 부각되었다. ${ }^{[39]}$ 온도가 내려가게 되면

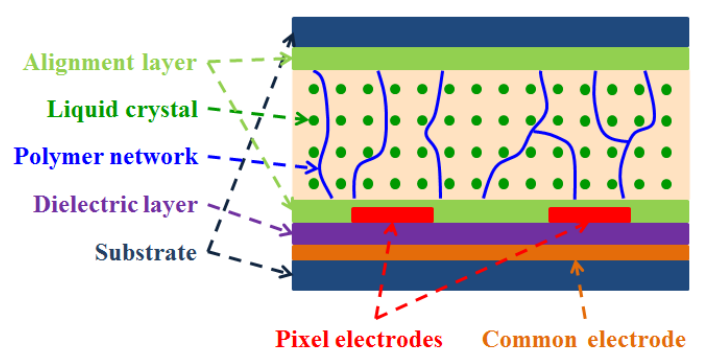

FIG. 15. Polymer-networked IPS cell. ${ }^{[39]}$

액정의 viscosity가 증가하게 되어 응답시간이 급격하게 증가 하게 되는 문제가 발생하게 된다. 이러한 문제점을 개선하기 위해 RM을 이용한 방법이 제안 되었다.(그림 15) 소량의 $\mathrm{RM}$ 을 이용해 셀 내부에 폴리머 네트웍을 형성하게 되었을 경우 폴리머 네트웍 형성 조건 및 RM 농도에 따라 저온에서 의 응답 시간을 최대 약 $45 \%$ 까지 개선할 수 있다.

한편, 음의 액정을 이용한 수평배향 액정모드 또한 활발히 연구되고 있다. ${ }^{[40]}$ 음의 액정을 이용하게 될 경우, 양의 액정 을 이용하는 경우보다 개구율 증가로 인한 투과율 개선 효과 와 함께 저주파수 구동이 가능하여 전력 소모를 줄일 수 있 다. 하지만 음의 액정의 큰 viscosity로 인한 느린 응답시간은 여전히 해결해야 할 문제로 남아있다.

\section{V. 결 론}

본 논문에서는 액정 디스플레이의 구조와 원리에 대해서 알아보고, 가장 널리 사용되고 있는 VA 모드와 IPS 모드 기 술에 대한 연구를 중심으로 소개하였다. 수많은 연구자들의 노력을 통해 액정 디스플레이는 빠른 속도로 발전해왔고, 현 재 정보디스플레이 시장에서 압도적인 시장 점유율을 유지 하고 있다. 최근 OLED와의 경쟁이 치열하게 전개되는 상황 에서 끊임없는 창의적이 노력을 이어진다면 정보디스플레이 의 미래는 더욱 밝아질 것이다.

\section{감사의 글}

이 논문은 2011년도 정부(교육과학기술부)의 재원으로 한 국연구재단의 지원을 받아 수행된 연구임(MEST, No. 20110029198).

\section{References}

1. P. Yeh and C. Gu, Optics of Liquid Crystal Displays, 2nd ed. (Wiley, 2010).

2. D.-K. Yang and S.-T Wu, Fundamentals of Liquid Crystal Devices (Wiley, 2006).

3. C.-J. Yu and S.-D. Lee, "Fundamentals of liquid crystal and liquid crystal optics," Korean J. Opt. Photon. (Hankook Kwanghak Hoeji) 24, 159-167 (2013). 
4. K.-H. Kim and T.-H. Yoon, "Reflective and transflective liquid crystal devices," Progress in Liquid Crystal Science and Technology, H.-S. Kwok, ed. (World Scientific, 2013), Chapter 27.

5. S. H. Lee, H. W. Do, G.-D. Lee, T.-H. Yoon, and J. C. Kim, "Electrooptic characteristics of new configuration for reflective in-plane switching liquid crystal device,” Jpn. J. Appl. Phys. 42, 7361-7365 (2003).

6. K.-H. Park, J. C. Kim, and T.-H. Yoon, "Horizontal switching of half-wave liquid crystal cell for transflective display,” Jpn. J. Appl. Phys. 44, 210-215 (2005).

7. E.-Y. Jeon, K.-H. Kim, J.-H. Lee, and T.-H. Yoon, "Single cell-gap transflective liquid crystal device created by controlling the pretilt angle using a liquid crystalline reactive monomer," Opt. Express 19, 25617-25622 (2011).

8. T.-H. Yoon, K.-H. Park, and J. C. Kim, "Design of transflective liquid crystal display devices," Optical Science and Technology 8(4), 35-45 (2004).

9. C.-J. Yu, J.-H. Kim, and S.-D. Lee, "Quasi-achromatic and wide viewing properties of a reflective liquid crystal display in in-plane optical geometry," Jpn. J. Appl. Phys. 41, 5298-5301 (2002).

10. J.-H. Kim and S. H. Lee, "LCD: basic principle and development trend," Optical Science and Technology 7(4), 7-14 (2003).

11. K.-H. Kim, D. H. Song, H.-J. Jin, and T.-H. Yoon, "Single panel liquid crystal device switchable between reflective and transmissive modes," J. Phys. D: Appl. Phys. 44, 295101 (2011).

12. C. Z. van Doorn, "Dynamic behavior of twisted nematic liquid-crystal layers in switched fields," J. Appl. Phys. 46, 3738-3745 (1975).

13. S. S. Kim, “The world's largest (82-in) TFT-LCD," SID. Int. Symp. Dig. Tech. Pap. 36, 1842-1847 (2005).

14. J.-I. Baek, K.-H. Kim, J. C. Kim, T.-H. Yoon, H. S. Woo, S. T. Shin, and J. H. Souk, "Fast switching of vertical alignment liquid crystal cells with liquid crystalline polymer networks," Jpn. J. Appl. Phys. 48, 056507 (2009).

15. J. S. Gwag, K.-S. Bae, Y.-J. Lee, and J.-H. Kim, "Electro-optical characteristics of omnidirectional liquid crystal domain mode using doughnut-shaped slit electrode," J. Appl. Phys. 105, 073107 (2009).

16. M. Oh-e and K. Kondo, "Electro-optical characteristics and switching behavior of the in-plane switching mode," Appl. Phys. Lett. 67, 3895-3897 (1995).

17. S. H. Lee, S. L. Lee, and H. Y. Kim, "Electro-optic characteristics and switching principle of a nematic liquid crystal cell controlled by fringe-field switching," Appl. Phys. Lett. 73, 2881-2883 (1998).

18. R. A. Soref and M. J. Rafuse, "Electrically controlled birefringence of thin nematic films," J. Appl. Phys. 43, 2029-2037 (1972).

19. H. K. Shin, J. H. Lee, J.-W. Kim, T.-H. Yoon, and J. C. Kim, "Fast polarization switching panel with high brightness and contrast ratio for three-dimensional display," Appl. Phys. Lett. 98, 063505 (2011).

20. H. Kikuchi, M. Yokota, Y. Hisakado, H. Yang, and T. Kajiyama, "Polymer-stabilized liquid crystal blue phase," Nature Mater. 1, 64-68 (2002).

21. Y.-H. Kim, S.-T. Kim, C.-S. Park, K.-W. Park, S.-W. Choi, S.-W. Kang, and H.-R. Kim, "A vertical-field-driven polymer-stabilized blue phase liquid crystal mode to obtain a higher transmittance and lower driving voltage," Opt. Express 19, 17427-17438 (2011).

22. T. Takahashi, H. Furue, M. Shikada, N. Matsuda, T. Miyama, and S. Kobayashi, "Preliminary study of field sequential full color liquid crystal display using polymer stabilized ferroelectric liquid crystal display," Jpn. J. Appl. Phys. 38, L534-L536 (1999).

23. S. H. Lee, K.-H. Park, T.-H. Yoon, and J. C. Kim, "Bistable chiral-splay nematic liquid crystal device using horizontal switching," Appl. Phys. Lett. 82, 4215-4217 (2003).

24. D. H. Song, K.-H. Kim, J.-W. Kim, J. C. Kim, and T.-H. Yoon, "Dual-mode operation of a twisted nematic liquid crystal cell by switching between dynamic and memory modes," Opt. Lett. 36, 2077-2079 (2011).

25. J. H. Lee, D. H. Song, T. Kim, H. K. Shin, C. G. Jhun, S.-B. Kwon, D.-G. Kim, W. S. Kim, T.-H. Yoon, and J. C. Kim, "Reflective dual mode liquid crystal display with dynamic mode utilizing the transition behavior between the two stable states of its memory mode," Jpn. J. Appl. Phys. 50, 084101 (2011).

26. K. Hanaoka, Liquid Crystal Display and Method of Manufacturing the Same, US Patent 7113241 (2006).

27. K.-H. Kim, E.-Y. Jeon, B. W. Park, D. H. Song, J.-H. Lee, G. S. Lee, K.-C. Shin, H. S. Kim, and T.-H. Yoon, "Pixel electrode structure for high transmittance in a multi-domain vertical alignment liquid crystal display device," J. Phys. D: Appl. Phys. 45, 065103 (2012).

28. S. B. Park, J.-K. Song, Y. Um, and K.-H. Kim, "Pixeldivision technology for high-quality vertical-alignment LCDs," IEEE Electr. Device. Lett. 31, 987-989 (2010).

29. J.-H. Lee, H. Jin, J.-W. Kim, K.-H. Kim, B.-W. Park, T.-H. Yoon, H. Kim, K.-C. Shin, and H. S. Kim, "Formation of liquid crystal multi-domains with different threshold voltages by varying the surface anchoring energy," J. Appl. Phys. 112, 054107 (2012).

30. S.-W. Choi, H. Jin, K.-H. Kim, J.-H. Lee, H. Kim, K.-C. Shin, H. S. Kim, and T.-H. Yoon, "Formation of dual threshold in a vertical alignment liquid crystal device," J. Opt. Soc. Korea 16, 170-173 (2012).

31. S. G. Kim, S. M. Kim, Y. S. Kim, H. K. Lee, S. H. Lee, G.-D. Lee, J.-J. Lyu, and K. H. Kim, "Stabilization of the liquid crystal director in the patterned vertical alignment mode through formation of pretilt angle by reactive mesogen," Appl. Phys. Lett. 90, 261910 (2007).

32. Y.-J. Lee, Y.-K. Kim, C.-J. Yu, S. I. Jo, and J.-H. Kim, "Fabrication of fast switchable patterned vertical alignment 
mode using modified surface with reactive mesogen," SID Int. Symp. Dig. Tech. Pap. 40, 666-668 (2009).

33. S. H. Lee, H. Y. Kim, I. C. Park, B. G. Rho, J. S. Park, H. S. Park, and C. H. Lee. "Rubbing-free, vertically aligned nematic liquid crystal display controlled by in-plane field," Appl. Phys. Lett. 71, 2851-2853 (1997).

34. D. $\mathrm{Xu}, \mathrm{L}$. Rao, C.-D. Tu, and S.-T. Wu, "Nematic liquid crystal display with submillisecond grayscale response time," J. Display Technol. 9, 67-70 (2013).

35. S. I. Park, K.-H. Park, J.-H. Lee, J. H. Yoon, B. K. Kim, B.-H. Yu, K.-H. Kim, and T.-H. Yoon, "Dark-state color shift and gray scale inversion in an in-plane switching liquid crystal display device,” J. Opt. Soc. Korea 16, 409-413 (2012).

36. D. H. Song, K.-H. Kim, and T.-H. Yoon, "High-transmittance in-plane switching liquid crystal display device driven by three-level voltages," J. Soc. Inf. Disp. 21, 29-33 (2013).
37. J.-I. Baek, K.-H. Kim, J. C. Kim, T.-H. Yoon, H. S. Woo, S. T. Shin, and J. H. Souk, "Fast in-plane switching of a liquid crystal cell triggered by a vertical electric field," Jpn. J. Appl. Phys. 48, 104505 (2009).

38. D. H. Song, J.-W. Kim, K.-H. Kim, S. J. Rho, H. Lee, H. Kim, and T.-H. Yoon, "Ultrafast switching of randomly-aligned nematic liquid crystals," Opt. Express 20, 11659-11664 (2012).

39. B.-H. Yu, D. H. Song, K.-H. Kim, B.-W. Park, S.-W. Choi, S. I. Park, S. G. Kang, J. H. Yoon, B. K. Kim, and T.-H. Yoon, "Formation of polymer networks for fast in-plane switching of liquid crystals at low temperature," Jpn. J. Appl. Phys. to be published.

40. J. H. Lee, K. H. Park, S. H. Kim, H. C. Choi, B. K. Kim, and Y. S. Yin, "AH-IPS, superb display for mobile device," SID Int. Symp. Dig. Tech. Pap. 44, 32-33 (2013). 